\title{
Influence of Incorporation of Natural Fibers on the Physical, Mechanical, and Thermal Properties of Composites LDPE-Al Reinforced with Fique Fibers
}

\author{
Miguel A. Hidalgo-Salazar, ${ }^{1}$ Mario F. Muñoz, ${ }^{1}$ and José H. Mina ${ }^{2}$ \\ ${ }^{1}$ Research Group GITEM, Universidad Autónoma de Occidente, Cali 760031, Colombia \\ ${ }^{2}$ Composite Materials Group, Universidad del Valle, Cali 760032, Colombia \\ Correspondence should be addressed to Miguel A. Hidalgo-Salazar; mahidalgo@uao.edu.co
}

Received 14 January 2015; Revised 18 March 2015; Accepted 19 March 2015

Academic Editor: Adriana Gregorova

Copyright (c) 2015 Miguel A. Hidalgo-Salazar et al. This is an open access article distributed under the Creative Commons Attribution License, which permits unrestricted use, distribution, and reproduction in any medium, provided the original work is properly cited.

\begin{abstract}
This study shows the effect of the incorporation of natural fique fibers in a matrix formed by low-density polyethylene and aluminum (LDPE-Al) obtained in the recycling process of long-life Tetra Pak packaging. The reinforcement content was 10, 20, and 30\% fibers, manufactured by hot-press compression molding of composite boards (LDPE-Al/fique). From the thermogravimetric analysis (TGA) it was determined that the proportions of the LDPE-Al were $75: 25 \mathrm{w} / \mathrm{w}$. Likewise, it was found that the aluminum particles increased the rigidity of the LDPE-Al, reducing the impact strength compared to LDPE recycled from Tetra Pak without aluminum; besides this, the crystallinity in the LDPE-Al increased with the presence of aluminum, which was observed by differential scanning calorimetry (DSC). The maximum strength and Young's modulus to tensile and flexural properties increased with the incorporation of the fibers, this increase being a direct function of the amount of reinforcement contained in the material. Finally, a reduction in the density of the compound by the generation of voids at the interface between the LDPE-Al and fique fibers was identified, and there was also a greater water absorption due to weak interphase fiber-matrix and the hydrophilic fibers contained in the material.
\end{abstract}

\section{Introduction}

In industry, composite materials have attracted great interest due to their good specific properties. These are evaluated according to the materials' mechanical performance, which depends on the characteristics of each of their components, the arrangement of the reinforcement in the matrix, and interfacial quality. In recent years, interest has grown worldwide in the incorporation of cellulosic fibers such as sisal, fique, jute, henequen, and wood pulp, among others, in composites, because present studies show that for their good mechanical properties the fibers can act as reinforcing polymeric matrices [1-6].

Among natural fibers, it can be highlighted that fique has an average density of $1.47 \mathrm{~g} / \mathrm{cm}^{3}$, a diameter (equivalent to the area) of around $0.24 \mu \mathrm{m}$, an ultimate strength of approximately $132.40 \mathrm{MPa}$, and Young's modulus between 8.20 and $9.10 \mathrm{GPa}$. This fiber is produced in different departments of
Colombia, mainly Cauca, Nariño, Santander, and Antioquia, which produce $98 \%$ of the fiber in the country [7-11].

Moreover, the trend in the state of the art tends to point toward polymeric matrices coming from renewable sources or recycling processes involving high turnover products. Amongst the latter class of materials are mixtures of lowdensity polyethylene and aluminum (LDPE-Al) obtained from the recycling of long-life Tetra Pak packaging, which are composed of $5 \%$ aluminum, $20 \%$ polyethylene, and $75 \%$ paperboard. Neves in 1999 reported the basic process to the industrial recycling of the Tetra Pak packaging, mainly based on the separation of the paperboard layer of the aluminum and polyethylene layers by hydropulping process for $35 \mathrm{~min}$, where cellulosic fiber was obtained suitable for use in different papermaking process, while the LDPE-Al's residue could be used in power generation (through incineration) or in the manufacture of plastics elements, such as chipboards; also, it is possible to recover the aluminum by pyrolysis $[9,12]$. 
Mourad et al., 2008 [13], analyzed the influence of recycling of the Tetra Pak packaging on the reduction of Global Warming Potential (GWP); they determined that an increase in recycling from $2 \%(2000)$ to $22 \%$ (2004) reduces the GWP in more than $14 \%$, and a $48 \%$ could be reached if the recycling of Tetra Pak packaging increases to $70 \%$.

Due to the global interest, particularly by the Tetra Pak company, in the recovery and reuse of LDPE-Al, in this work we studied the influence of incorporating fique fibers in a matrix based on a binary mixture of LDPE and aluminum (LDPE-Al) on some physical, thermal, and mechanical properties of composite LDPE-Al/fique. The material is manufactured by the hot-plate press molding process with fique contents of 10,20 , and $30 \%$ by volume; these values of contents were determined from previous works, where it was observed that using the same process implemented in this work it is difficult to achieve a good distribution of the fibers in the composite and complete wetting of the fibers with the matrix when content of fiber is above $30 \%$ [9]. The characterization focused primarily on the tensile, flexural, and impact mechanical performance of the material. Also, we evaluated the influence of the fibers on the heat stability, crystallinity, density, and water absorption of the material.

\section{Materials}

The LDPE-Al without cellulose used in this research as composite matrix, supplied by INNOPACK LTDA, was processed in order to reduce its particle size. The material has a LDPE/aluminum ratio of $89.75 / 10.25 \mathrm{v} / \mathrm{v}$ by volume and a density of $1.10 \mathrm{~g} / \mathrm{cm}^{3}$. Fique fibers belonged to the (white) eagle claw variety of the Furcraea genus and were supplied by Compañia de Empaques de Medellin; these fibers were used without any treatment and were arranged in the compound as a two-dimensional mat with a random arrangement, as shown in Figure 1. The fique employed had an average length of $51.70 \pm 33 \mathrm{~mm}$, maximum tensile strength of $263.65 \mathrm{MPa}$, average Young's modulus of $8.64 \pm 0.71 \mathrm{GPa}$ (measured with fiber lengths of $50 \mathrm{~mm}$ ), and true density of approximately $1.102 \mathrm{~g} / \mathrm{cm}^{3}[11,14]$.

\section{Experimental Procedures}

3.1. Preparation of Composite and Specimens. The composite material formed with the binary mixture LDPE-Al as a matrix and fique as reinforcing fibers (LDPE-Al/fique) was obtained as rectangular boards with dimensions of $290 \times 290 \times 2 \mathrm{~mm}$, using for this purpose one hot-plate press and a forced water circulation cooling system (LabPro 400, Fontijne Presses). To shape the specimens, stainless steel close-up type molds were used, where layers of LDPE-Al and fique fiber mats (to reach the desired percentages of fibers of 10, 20, and 30\% fiber volume) were alternately placed. The molding was conducted at a temperature of $170^{\circ} \mathrm{C}$ and a pressure of $3 \mathrm{MPa}$; the complete process was $15 \mathrm{~min}$, comprising $11 \mathrm{~min}$ of heating and $4 \mathrm{~min}$ of cooling under pressure (Figure 2). Finally the boards were demolded and adjusted to the required dimensions in various



FIGURE 1: Dimensional randomization of fique mat used in the reinforcement of the LDPE-Al.

mechanical (tensile, flexural, and impact), physical (density, water absorption), and thermal (thermogravimetry and differential scanning calorimetry, DSC) tests using a numerical control router.

3.2. Mechanical Tests. Tensile mechanical properties were determined on samples of LDPE-Al matrix and the three LDPE-Al/fique composites with 10, 20, and 30\% reinforcement. In all cases this characterization was performed after 48 hours of conditioning at a temperature of $25^{\circ} \mathrm{C}$ and relative humidity of $50 \%$. The tests were conducted on an Instron 3366 mechanical universal testing machine fitted with a $10 \mathrm{kN}$ load cell. Type I specimens were used and tested with a speed of displacement between clamps of $5 \mathrm{~mm} / \mathrm{min}$ following the ASTM standard D638. All measurements were carried out on five test specimens and the analysis took into account the average of these ratings.

Through the flexural test, the mechanical flexural properties of LDPE-Al with and without reinforcement were measured. The materials were subjected to 48 hours of conditioning at a relative humidity of $50 \%$ and a temperature of $25^{\circ} \mathrm{C}$. The tests were carried out on an Instron 3366 universal mechanical testing machine equipped with a $10 \mathrm{kN}$ load cell. The specimens used had dimensions of $12.70 \mathrm{~mm} \times$ $100 \mathrm{~mm} \times$ thickness (thickness varied depending on the compound) and were evaluated at a speed within the range of $0.79-1.01 \mathrm{~mm} / \mathrm{min}$ (the rate was determined based on the dimensions of the specimen). The distance between the supports was 16 times the thickness of the specimen and the test was conducted up to 5\% strain, following the ASTM D790 standard. All measurements were carried out on five test specimens and the analysis took into account the average of these ratings.

The impact strength of LDPE-Al and LDPE-Al/fique for the three compounds was determined. Prior to the test, the materials were subjected to conditioning for 48 hours at $50 \%$ relative humidity and a temperature of $25^{\circ} \mathrm{C}$. Trials were performed on an Izod Tinius Olsen impact pendulum equipped with a $4.53 \mathrm{~N}$ pendulum. The specimens were made following the standard ASTM D256, and the starting angle of the test was $55.80^{\circ}$. All measurements were carried out on five test specimens and the analysis took into account the average of these ratings. 

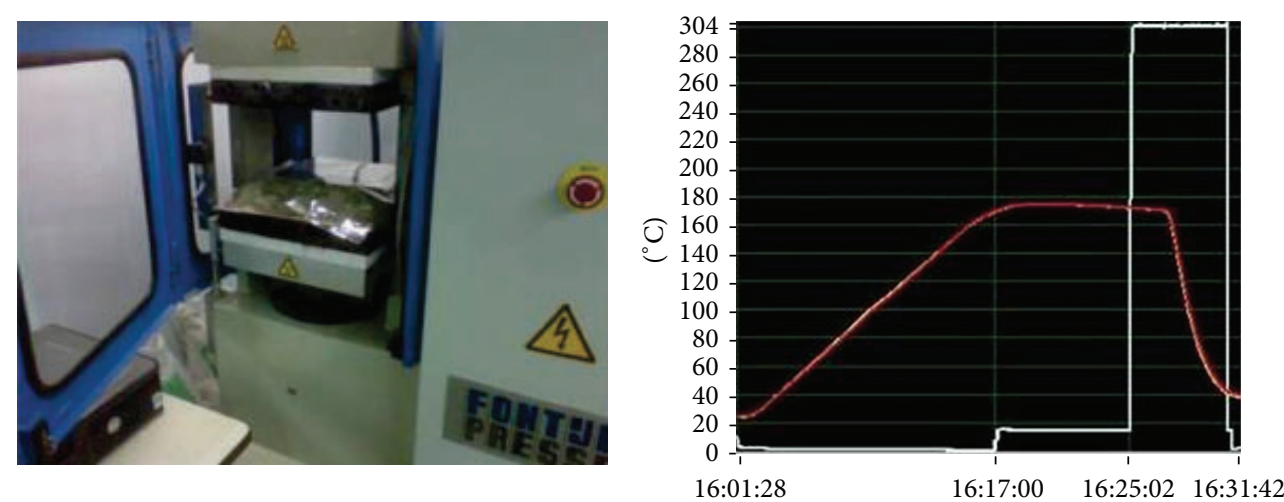

FIGURE 2: Manufacturing process of the boards produced from the LDPE-Al/fique compound.

3.3. Physical and Thermal Tests. The determination of the LDPE-Al and the three different compounds' (LDPE-Al/ fique) density was performed according to the Archimedes method specified in ASTM D792. Due to the hydrophilic character of the fibers present in fique, the conventional density test consisting of immersion in distilled water was discarded; canola oil was used as the immersion liquid, which has a density of $0.911 \mathrm{~g} / \mathrm{cm}^{3}$.

The water absorption test determined the ability of the LDPE-Al and the three compounds (LDPE-Al/fique) to absorb water at a set time. First, the materials were conditioned in an oven for $24 \mathrm{~h}$ at $50^{\circ} \mathrm{C}$; after this time had expired, conditioned specimens were weighed (conditioned weight) before being immersed in distilled water at a temperature of $25^{\circ} \mathrm{C}$ for $24 \mathrm{~h}$. Finally, the water was removed, the specimens were surface-dried and weighed (wet weight), and the determination of the percentage of water absorbed was performed according to the model specified in the following:

$$
\begin{aligned}
& \text { Weight increment, } \% \\
& =\frac{\text { Wet Weight }- \text { Conditioned Weight }}{\text { Conditioned Weight }} * 100 \text {. }
\end{aligned}
$$

The thermogravimetric analysis test (TGA) was carried out on TA Instruments TGA Q500 with a protective nitrogen atmosphere; the test was run at a heating rate of $10^{\circ} \mathrm{C} / \mathrm{min}$ in a temperature range between 25 and $550^{\circ} \mathrm{C}$. The average weight of the samples tested was $6 \mathrm{mg}$.

Differential Scanning Calorimetry (DSC). The percentage crystallinity and the melting temperature of the LDPE-Al matrix, as well as the influence of the incorporation of fibers in the LDPE-Al/fique composite, were determined using a Q2000 DSC equipment from TA Instruments under a protective atmosphere of nitrogen, with a heating and cooling speed of $10^{\circ} \mathrm{C} / \mathrm{min}$. Tests were carried out in three steps: (1) first heating: $-90^{\circ} \mathrm{C}$ to $150^{\circ} \mathrm{C}$ with an isotherm at $150^{\circ} \mathrm{C}$ for $4 \mathrm{~min}$; (2) cooling: $150^{\circ} \mathrm{C}$ to $-90^{\circ} \mathrm{C}$ with an isotherm at $-90^{\circ} \mathrm{C}$ for $3 \mathrm{~min}$; (3) second heating: $-90^{\circ} \mathrm{C}$ to $150^{\circ} \mathrm{C}$. The percentage crystallinity was estimated using the model presented in the following:

$$
X=\frac{\Delta H_{f}}{W_{\mathrm{pe}} \Delta H_{f}^{0}},
$$

where $X$ is the percentage crystallinity, $\Delta H_{f}$ is the compound's fusion enthalpy, $\Delta H_{f}{ }^{0}$ is the $100 \%$ crystalline polyethylene's fusion enthalpy (288.83 J/gr), and $W_{\text {pe }}$ is the weight fraction of the polyethylene phase in the compound $[15,16]$.

\section{Results and Discussion}

4.1. Tensile Test. Figure 3 shows the maximum strength, Young's modulus, and maximum strain values for each material tested. Here it can be demonstrated that increasing the fiber content in the compound led to increases in the maximum strength and Young's modulus and a decrease in the strain of the material, revealing that the material undergoes a phenomenon of stiffening due to the inclusion of natural fibers. This behavior might be generated by the high aspect ratio of the embedded fibers (average of 247), which causes the fique properties to prevail over those of LDPE-Al. Accordingly, it is worth noting that Hidalgo et al. [9], in a similar work about a polyethylene-aluminomatrix reinforced with short fiber of fique, suggested the possible presence of mechanical anchors between the fibers and the matrix, which would restrict the strain capacity of LDPE-Al. Moreover, if one considers that the fibers of fique mats, which are used in this work, have a random distribution and could be tangled with each other, the possible mechanical anchorage between the fibers and the matrix could be even more important.

The best tensile mechanical performance was obtained by the $30 \%$ fique fiber compound, resulting in a maximum strength and Young's modulus of $21.22 \mathrm{MPa}$ and $1.56 \mathrm{GPa}$, respectively. This implied increases of $97.80 \%$ in the maximum strength and $180.78 \%$ in Young's modulus relative to the material without reinforcement (LDPE-Al). It is important to remark that the maximum tensile strength was higher than that reported by Hidalgo et al. [9], who achieved a maximum tensile strength of $15.56 \mathrm{MPa}$ for a composite of LDPE-Al matrix reinforced with $30 \%$ short fique fibers. However, the 

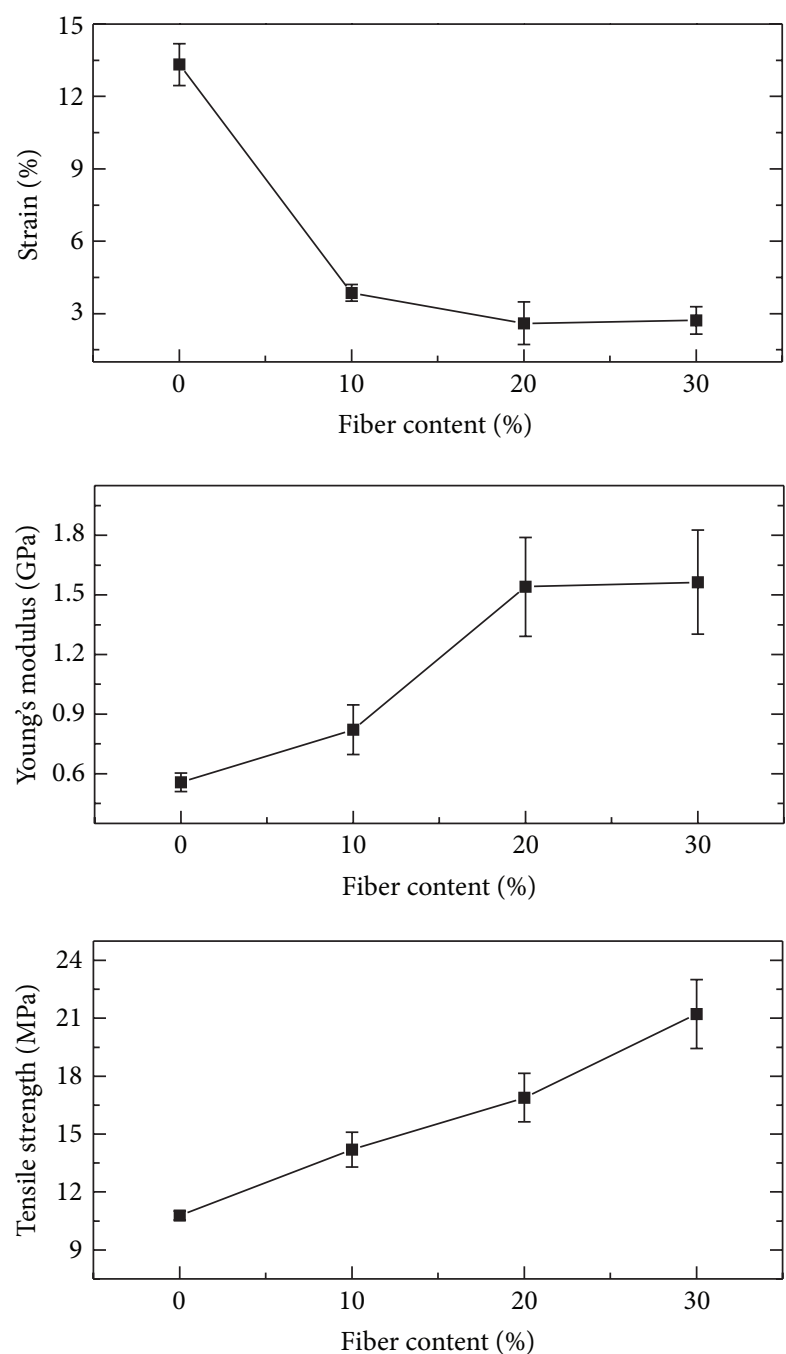

FIgURE 3: Tensile properties of the materials tested.

strain of this compound showed a decrease of $389.41 \%$ compared to the LDPE-Al.

4.2. Flexural Test. The bending behavior of the materials studied is shown in Figure 4. Here it can be observed that the properties increased when the incorporation of fique fibers increased in the LDPE-Al matrix, corroborating the stiffness that was previously evidenced in the tensile tests.

Just as in the tensile tests, the best performance was observed in the material reinforced with $30 \%$ fique fibers, which reached values of $26.97 \mathrm{MPa}$ to maximum strength and $1.37 \mathrm{GPa}$ to Young's modulus, improving the properties of LDPE-Al matrix by 117.81 and $204.28 \%$, respectively.

4.3. Impact Test. Figure 5 shows an impact strength of $10.47 \mathrm{~kJ} / \mathrm{m}^{2}(103.43 \mathrm{~J} / \mathrm{m})$ for the LDPE-Al; this value is less than that reported by Desiderá [17] for a LDPE recycled with Tetra Pak without aluminum $(315 \mathrm{~J} / \mathrm{m})$. This made it clear that the $10.50 \%$ aluminum particulate content in the polyethylene used as a matrix in this investigation weakens the material,
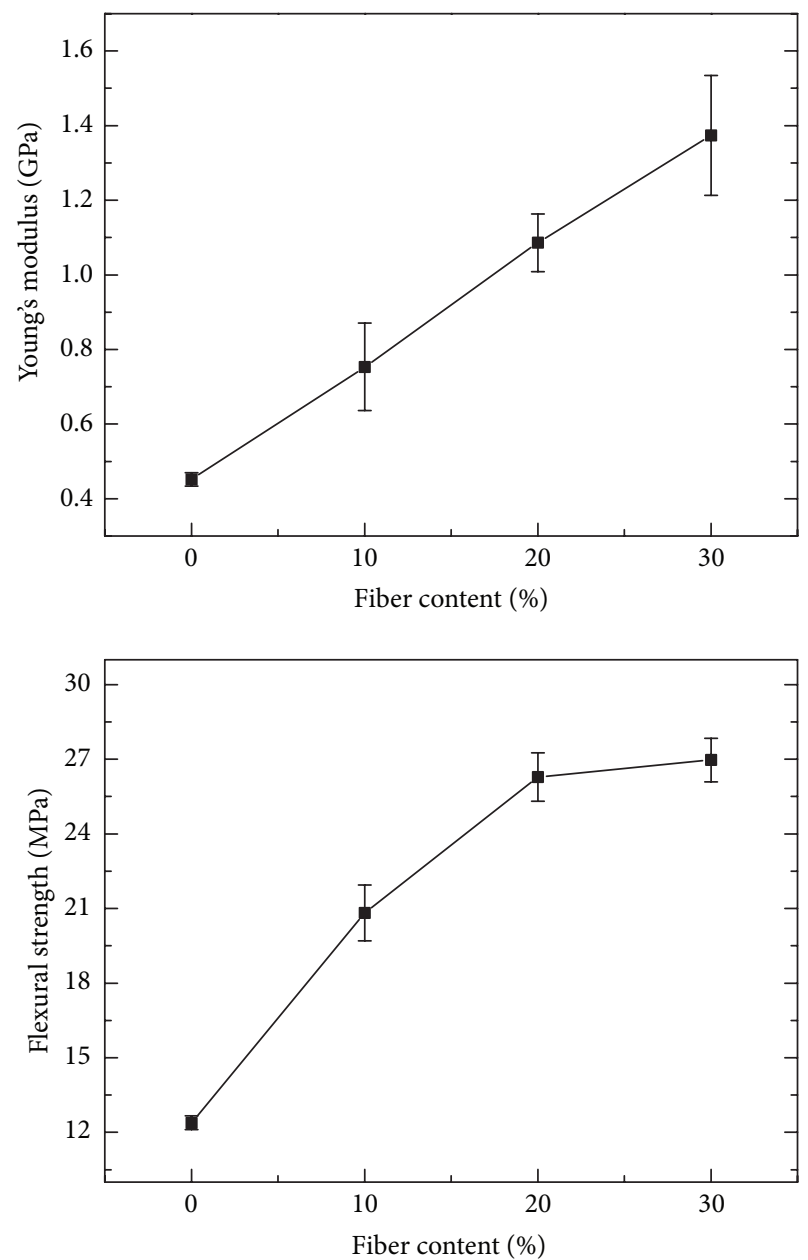

FIgURE 4: Flexural properties of the materials evaluated.

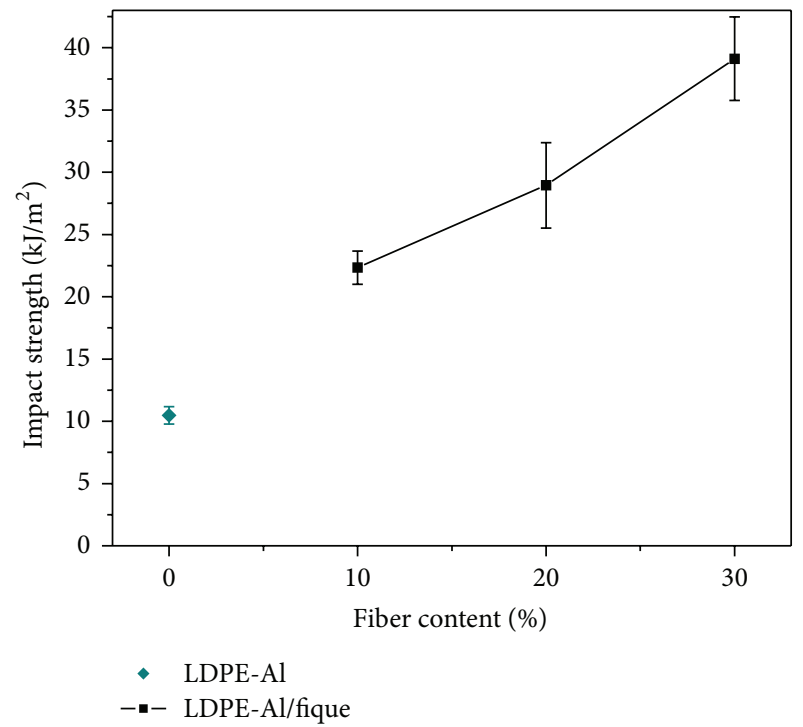

FIGURE 5: Impact strength of the composite depending on the fiber content.

generating a decrease in the ability of LDPE-Al to absorb energy; some authors that incorporated metal particles in 


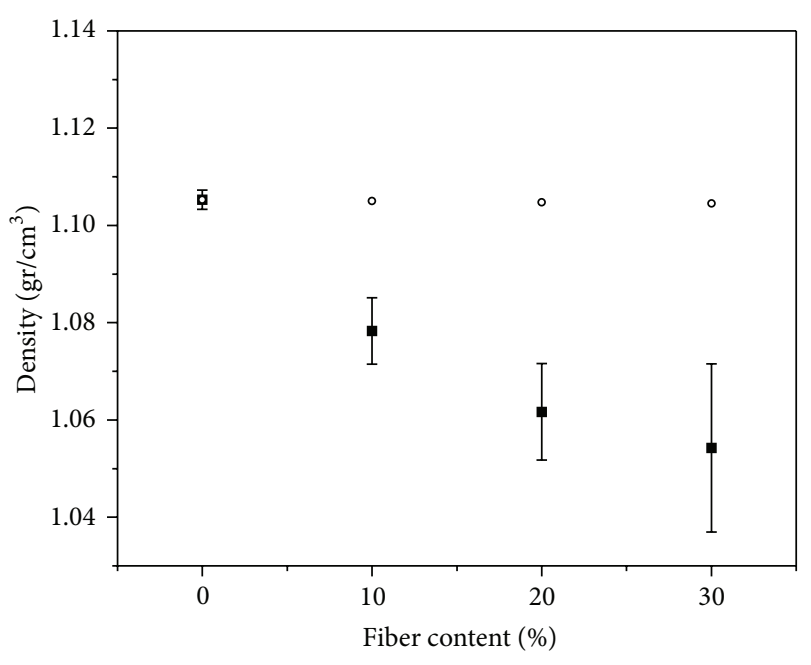

- Experimental data

- Theoretical data

Figure 6: Density of LDPE-Al and 10, 20, and 30\% fique fiber compounds.

polymeric matrices observed the same behaviour on impact strength and attributed it to weak interfacial adhesion in the composite, which generates that metallic particles behave as stress concentration points, facilitating the propagation of cracks in the material [17-19].

Moreover, it was found that, by incorporating fique fibers in the matrix, the material's impact strength increased. This phenomenon could be due to a possible energy absorption promoted by fracture mechanisms, which involve detachment, slippage, and fragmentation of the fiber and are not part of the unreinforced material fracture [20].

4.4. Density Test. Figure 6 shows the results obtained from the density tests of LDPE-Al and materials reinforced with 10,20 , and $30 \%$ fique fiber, and these results were compared with the density values estimated by the rule of mixtures.

By incorporating fique fibers, it was found that composite density decreased as the amount of fiber in the material increased. This occurred even though it was expected that the density of the compound would not undergo large variations with respect to the density of the LDPE-Al due to the similarity between the densities of LDPE-Al $\left(1.100 \mathrm{~g} / \mathrm{cm}^{3}\right)$ and fique $\left(1.102 \mathrm{~g} / \mathrm{cm}^{3}\right)$. This effect of the content of fique fibers on the composite density may be caused by the formation of a weak interface between the phases of the compound, which would affect the generation of voids and/or cavities between the fiber and the matrix; in Figure 7 a SEM micrograph can be observed, where the cavities present in the different materials evaluated are shown; hence the greater the amount of fibers in the material, the greater the difference between the experimental values and the value estimated by the rule of mixtures, as shown in the graphs presented in Figure 6. It is important to say that the standard deviations for the experimental values are higher when increasing the fique fiber content in the composite; this is associated with an increase in the rate of the weak fiber-matrix interface.

4.5. Water Absorption Test. Figure 8 shows the response of the materials evaluated to the water absorption after being immersed in distilled water for $24 \mathrm{~h}$ at $23^{\circ} \mathrm{C}$. The LDPE-Al without reinforcement had a water absorption percentage of $0.05 \%$, which increased with the fiber content incorporated. This is attributed to the possible water absorption by diffusion and percolation mechanisms; the latter phenomenon is generated by microspaces present between the fiber and the matrix, as seen in Figure 7, which allow the filtration of water on the material and it becomes more important when the fiber content on the matrix is increased. Another reason for the observed trend is the hydrophilic character of the cellulosic fibers, especially promoted by the hemicellulose content, which is considered as the fiber component with the highest water absorption capacity, because it has a disordered intermolecular structure which prevents its hydroxyl groups which can establish hydrogen bonds with each other, thus allowing the formation of bonds with water molecules [2123].

4.6. Thermogravimetric Analysis (TGA). TGA was performed on both the LDPE-Al and the material reinforced with $30 \%$ by volume of fique. Figure 9 shows the thermograms obtained in the materials evaluated. Here we can see an initial mass loss at a temperature close to $65^{\circ} \mathrm{C}$ in the reinforcement material, highlighting that this fall was not important in the LDPE-Al matrix. According to Monteiro et al. [24], the mass loss could be attributed to the loss of water in fique fibers (due to their hydrophilic state) contained in the composite. This reduction in mass was about $2.61 \%$.

Likewise, the thermogram of LDPE-Al (Figure 9) demonstrates that the onset of degradation of the LDPE occurred from $350^{\circ} \mathrm{C}$ and a faster loss of mass of the polyethylene was present around $470^{\circ} \mathrm{C}$, as the peak of the derivative curve DTG shows. These values were similar to those reported by Tajeddin et al. [25], who worked with a LDPE/kenaf composite. Moreover, one can see that the degradation of LDPE-Al reached a mass loss of around 75\%, which is only associated with the polyethylene phase because the aluminum phase does not suffer any loss of mass by volatilization at a temperature of $500^{\circ} \mathrm{C}[26]$, implying that the remaining $25 \%$ is aluminum. Given that the LDPE (with which the Tetra Pak packaging is manufactured) has a density of $0.918 \mathrm{~g} / \mathrm{cm}^{3}$ [26] and that the aluminum has a density of $2.70 \mathrm{~g} / \mathrm{cm}^{3}$, it was possible to confirm that the ratio $75 / 25 \mathrm{w} / \mathrm{w}$ that was determinate in the test is equivalent to the $89.75 / 10.25 \mathrm{v} / \mathrm{v}$ for $\mathrm{LDPE} / \mathrm{Al}$, previously established in Section 2.

Regarding the material reinforced with $30 \%$ fique fibers, it can be observed in thermogram (Figure 9) that before the LDPE thermal degradation occurred, thermal events associated with fique fibers occurred, which resulted in a loss of mass around $305^{\circ} \mathrm{C}$, which has been attributed by some researchers $[14,24]$ to the degradation of hemicellulose. Furthermore, another important mass loss can be observed in the range of 325 to $400^{\circ} \mathrm{C}$, corresponding to the thermal 

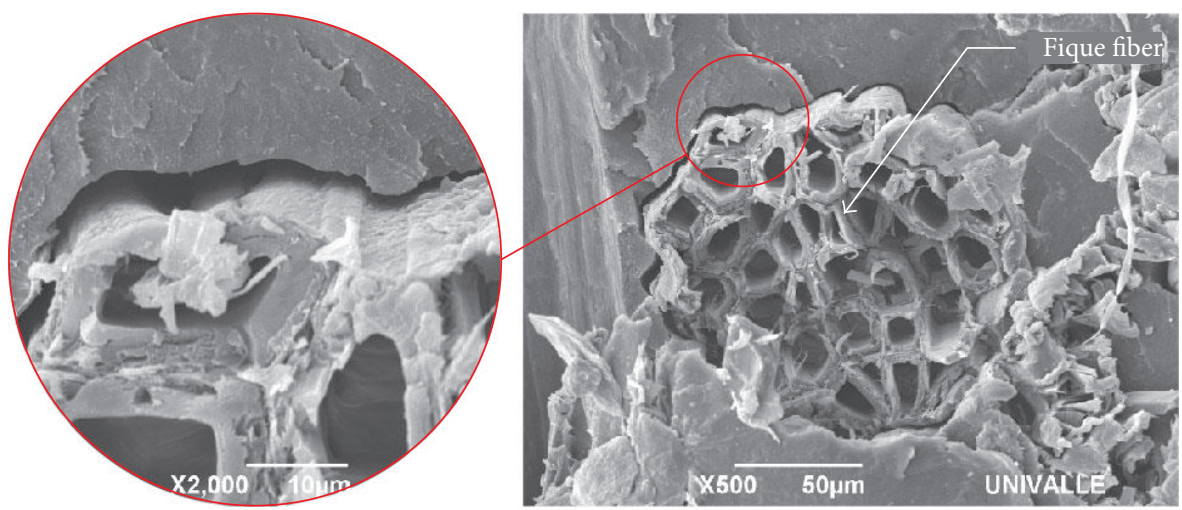

FIGURE 7: SEM micrograph. Cavities present in the fiber-matrix interface of the LDPE-Al/fique compound.

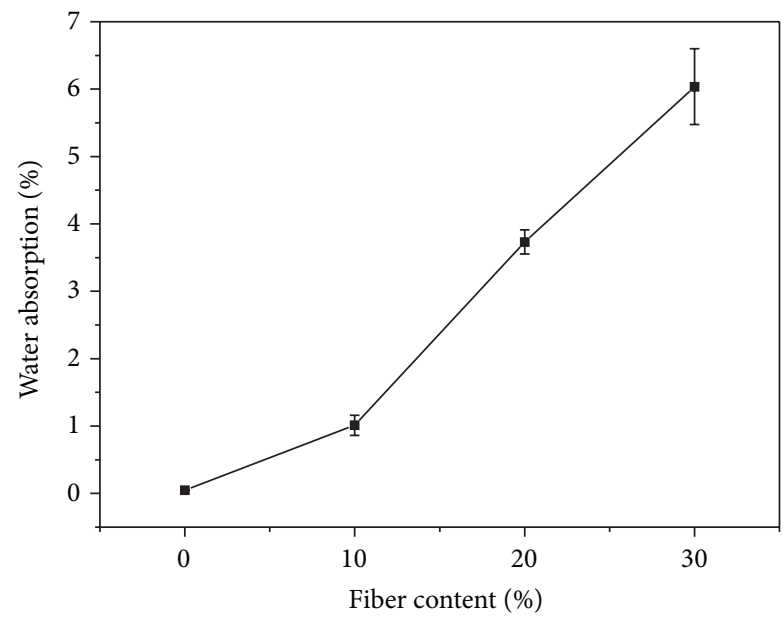

FIGURE 8: Water absorption by immersion of composite materials reinforced with fique fibers at $23^{\circ} \mathrm{C}$.

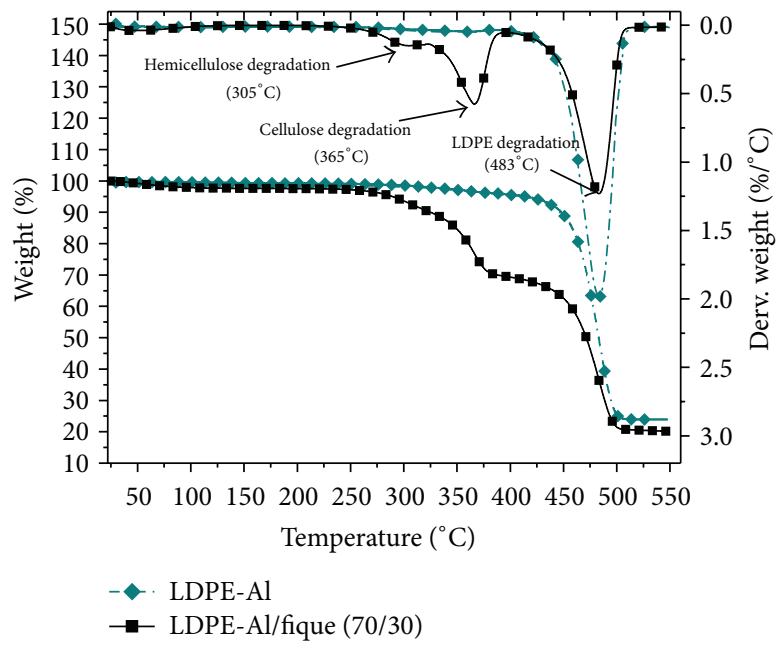

FIGURE 9: TGA thermogram for LDPE-Al compound and 30\% fique fibers compound.

degradation of cellulose and thus the decomposition of the fiber. Moreover, the peak of the derivative associated with

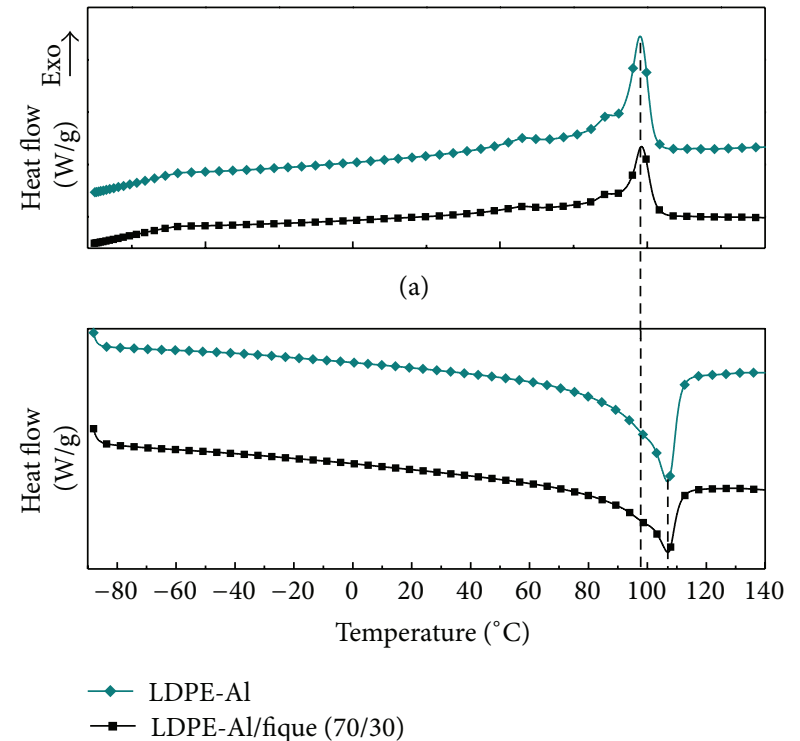

(b)

FIGURE 10: Heat flow versus temperature for LDPE-Al and 30\% fique fiber compound: (a) cooling and (b) second heating.

the decomposition of LDPE shows a shift to about $483^{\circ} \mathrm{C}$ in the reinforcing material. The increase in the thermal stability of the compound has been previously reported in different studies $[25,27,28]$, indicating that the incorporation of fibers in the material induces spherulite nucleation points, increasing the crystallinity of the polymer and, therefore, improving its thermal properties.

4.7. Differential Scanning Calorimetry (DSC). Just as with the TGA, the materials evaluated with this technique were $30 \%$ fique and LDPE-Al without reinforcement. Figure 10 shows the curves of heat flow as a function of temperature (cooling and second heating) for the materials tested. Here it can be observed that in the heating curves (Figure 10(b)) there is an apparent decrease in the enthalpy of fusion from 90.01 to $63.22 \mathrm{~J} / \mathrm{g}$ with increasing fraction of the material components (fique fibers and aluminum), which do not present melt at the 
TABle 1: Degree of crystallinity $(X)$ estimated for the polyethylene phase for each of the materials tested.

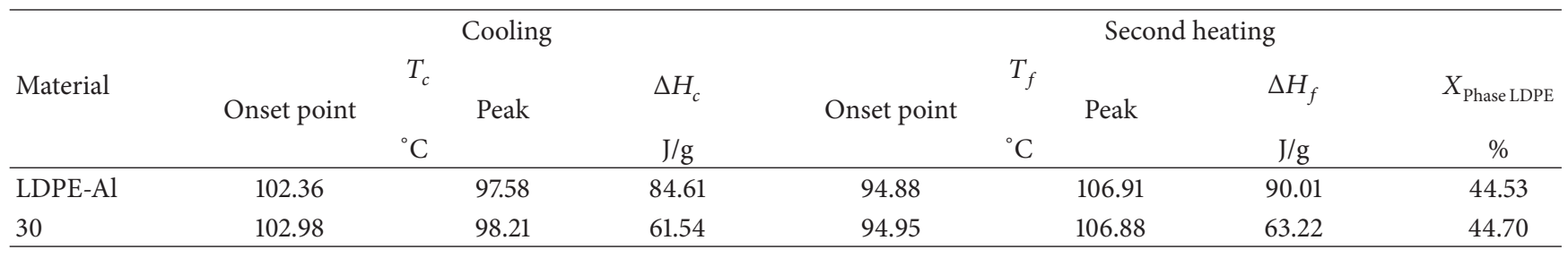

conditions of the test and are not miscible with the polyethylene phase; however, although the melting enthalpy of LDPE$\mathrm{Al} /$ fique appears to be smaller than that shown by the LDPE$\mathrm{Al}$ and the LDPE $(98-115 \mathrm{~J} / \mathrm{g})[16,17]$, when the melting enthalpy is corrected taking into account only the content of LDPE, the crystallinity of the polyethylene phase does not decrease (Table 1). This behavior was also observed by AhtOng and Charoenkongthum [29] in a biocomposite of LDPE/ banana starch.

Table 1 shows the degree of crystallinity $(X)$ estimated for the polyethylene phase for each of the materials tested. It was found that the crystallinity of the polyethylene phase within the LDPE-Al was $44.53 \%$, which was greater than the value of $34 \%$ reported in various studies $[16,30]$ for lowdensity polyethylene, which was also determined by DSC tests. Desiderá [17], who studied a mixture of polyamide and polyethylene recycled from multilayer recycled packaging, attributed the increase in crystallinity to the effect of the presence of aluminum particles and/or impurities present in the recycled material, which act as nucleation points promoting the formation of spherulites. Similarly, when comparing the degree of crystallinity obtained in the phase of the LDPEAl to that achieved in the fique-fiber-reinforced material, no significant difference can be seen. This crystalline phase content was maintained despite the decreasing fraction of aluminum in the composite owing to the incorporation of the fibrous material. The above shows that the fique fibers also promote the formation of crystalline phases in the polyethylene present in the matrix of the composite. In some studies $[14,21,31]$ of fiber-reinforced related compounds, it has also been found that fibers act effectively as nucleation sites for the formation of spherulites.

Furthermore, the melting of the materials presented a well-defined peak whose base was found around $107^{\circ} \mathrm{C}$. It is important to note that in some studies $[25,32,33]$ melting temperatures of 102 to $105^{\circ} \mathrm{C}$ are reported for virgin and recycled LDPE, which could suggest further evidence of increased crystallinity in the polyethylene phase, since more energy is required to reach the melting point of the material, particularly regarding the fusion of the crystalline fraction.

\section{Conclusions}

In this work it was possible to develop a composite material comprising a matrix based on low-density polyethylene and aluminum (LDPE-Al) obtained from the recycling of postconsumer long-life Tetra Pak packaging and fique fibers as reinforcement. Such material may be processed using a conventional processing method using hot compression molding.

With regard to the tensile and flexural properties, clear stiffening was observed with the addition of fique to LDPE$\mathrm{Al}$ attributed to the good aspect ratio of the fibers used and their arrangement in the matrix. The impact strength of the material increased due to the generation of energy-absorbing mechanisms during fracture, such as detachment, slippage, and fiber fracture, which were absent in the material without reinforcement.

Thermal analysis techniques such as TGA and DSC, allowed determining that the aluminum particles (dispersed phase present in the LDPE-Al) and the incorporation of fique fiber on the composite induce nucleation points of spherulites which promote increased crystallinity on the polyethylene phase of the materials evaluated in $10.7 \%$ (with reference LDPE without fibers or aluminum), leading to improved thermal properties, as evidenced by the shifting of the decomposition temperature peak of the LDPE, which moved from 470 to $483^{\circ} \mathrm{C}$ when fique fibers were incorporated.

Furthermore, the incorporation of fique fibers on the LDPE-Al caused a decrease in density and an increase of water absorption; this is due to the hydrophilic character of natural fibers that also generates the formation of a weak interface with the matrix, which influence the generation of voids and/or cavities in the material.

\section{Conflict of Interests}

The authors declare that there is no conflict of interests regarding the publication of this paper.

\section{References}

[1] A. K. Bledzki and J. Gassan, "Composites reinforced with cellulose based fibres," Progress in Polymer Science, vol. 24, no. 2, pp. 221-274, 1999.

[2] P. Wambua, J. Ivens, and I. Verpoest, "Natural fibres: can they replace glass in fibre-reinforced plastics?" Composites Science and Technology, vol. 63, no. 9, pp. 1259-1264, 2003.

[3] S. J. Eichhorn and R. J. Young, "Composite micromechanics of hemp fibres and epoxy resin microdroplets," Composites Science and Technology, vol. 64, no. 5, pp. 767-772, 2004.

[4] S. V. Joshi, L. T. Drzal, A. K. Mohanty, and S. Arora, "Are natural fiber composites environmentally superior to glass fiber reinforced composites?" Composites Part A: Applied Science and Manufacturing, vol. 35, no. 3, pp. 371-376, 2004. 
[5] M. Brahmakumar, C. Pavithran, and R. M. Pillai, "Coconut fibre reinforced polyethylene composites: effect of natural waxy surface layer of the fibre on fibre/matrix interfacial bonding and strength of composites," Composites Science and Technology, vol. 65, no. 3-4, pp. 563-569, 2005.

[6] P. J. Herrera-Franco and A. Valadez-González, "A study of the mechanical properties of short natural-fiber reinforced composites," Composites Part B: Engineering, vol. 36, no. 8, pp. 597608, 2005.

[7] P. Gañán and I. Mondragon, "Fique fiber-reinforced polyester composites: effects of fiber surface treatments on mechanical behavior," Journal of Materials Science, vol. 39, no. 9, pp. 31213128, 2004.

[8] M. A. Hidalgo, M. F. Muñoz, and K. J. Quintana, "Mechanical behavior of polyethylene aluminum composite reinforced with continuous agro fique fibers," Revista Latinoamericana de Metalurgia y Materiales, vol. 31, no. 2, pp. 187-194, 2011.

[9] M. Hidalgo, M. Muñoz, and K. Quintana, "Mechanical analysis of polyethylene aluminum composite reinforced with short fique fibers available a in two-dimensional arrangement," Revista Latinoamericana de Metalurgia y Materiales, vol. 32, no. 1, pp. 89-95, 2012.

[10] J. H. Mina, "Physico-mechanical characterization of thermoplastic cassava starch (TPS) and interfacial analysis with fique fibers," Biotecnología en el Sector Agropecuario y Agroindustrial, vol. 10, pp. 99-109, 2012.

[11] M. F. Muñoz-Velez, M. A. Hidalgo-Salazar, and J. H. MinaHernandez, "Fique fiber an alternative for reinforced plastics. Influence of surface modification," Biotecnología en el Sector Agropecuario y Agroindustrial, vol. 12, no. 2, pp. 60-70, 2014.

[12] F. L. Neves, "Reciclagem de embalagens cartonadas Tetra Pak," O Papel, vol. 53, no. 2, pp. 38-45, 1999.

[13] A. L. Mourad, E. E. C. Garcia, G. B. Vilela, and F. von Zuben, "Influence of recycling rate increase of aseptic carton for longlife milk on GWP reduction," Resources, Conservation and Recycling, vol. 52, no. 4, pp. 678-689, 2008.

[14] M. A. Hidalgo, J. H. Mina, and P. J. Herrera, "The effect of interfacial adhesion on the creep behaviour of LDPE-Al-Fique composite materials," Composites Part B: Engineering, vol. 55, pp. 345-351, 2013.

[15] C. Guerrero, T. Lozano, V. Gonzales, and E. Arroyo, "Morfologia y propiedades de politereftalato de etilen-glicol y polietileno de alta densidad," Ciencia UANL, vol. 6, no. 2, pp. 203-211, 2003.

[16] Y. Habibi, W. K. El-Zawawy, M. M. Ibrahim, and A. Dufresne, "Processing and characterization of reinforced polyethylene composites made with lignocellulosic fibers from Egyptian agro-industrial residues," Composites Science and Technology, vol. 68 , no. 7-8, pp. 1877-1885, 2008.

[17] C. Desiderá, Blendas de poliamida reciclada e polietileno proveniente da recuperação de embalagens multicamadas [PhD dissertation], Universidade Estadual de Campinas, 2007.

[18] K. Ghosh and S. N. Maiti, "Mechanical properties of silver-powder-filled polypropylene composites," Journal of Applied Polymer Science, vol. 60, no. 3, pp. 323-331, 1996.

[19] A. Gungor, "The physical and mechanical properties of polymer composites filled with Fe powder," Journal of Applied Polymer Science, vol. 99, no. 5, pp. 2438-2442, 2006.

[20] B. Bax and J. Müssig, "Impact and tensile properties of PLA/ Cordenka and PLA/flax composites," Composites Science and Technology, vol. 68, no. 7-8, pp. 1601-1607, 2008.
[21] M. E. Vallejos, Aprovechamiento integral del cannabis sativa como material de refuerzo/carga del polipropileno [Ph.D. thesis], Universitat de Girona, Girona, Spain, 2006.

[22] W. Wang, M. Sain, and P. A. Cooper, "Study of moisture absorption in natural fiber plastic composites," Composites Science and Technology, vol. 66, no. 3-4, pp. 379-386, 2006.

[23] S. M. L. Rosa, E. F. Santos, C. A. Ferreira, and S. M. B. Nachtigalt, "Studies on the properties of rice-husk-filled-PP compositeseffect of maleated PP," Materials Research, vol. 12, no. 3, pp. 333338, 2009.

[24] S. N. Monteiro, V. Calado, R. J. S. Rodriguez, and F. M. Margem, "Thermogravimetric behavior of natural fibers reinforced polymer composites-an overview," Materials Science and Engineering A, vol. 557, no. 15, pp. 17-28, 2012.

[25] B. Tajeddin, R. A. Rahman, L. C. Abdulah, N. A. Ibrahim, and Y. A. Yusof, "Thermal properties of low density polyethylenefilled kenaf cellulose composites," European Journal of Scientific Research, vol. 32, no. 2, pp. 223-230, 2009.

[26] C. M. A. Lopes and M. I. Felisberti, "Composite of low-density polyethylene and aluminum obtained from the recycling of postconsumer aseptic packaging," Journal of Applied Polymer Science, vol. 101, no. 5, pp. 3183-3191, 2006.

[27] A. Stamboulis, C. Baillie, and E. Schulz, "Interfacial characterisation o flax fibre-thermoplastic polymer composites by the pull-out test," in Proceedings of the 2nd International Wood and Natural Fibre Composites Symposium, Kassel, Germany, June 1999.

[28] P. Gañán and I. Mondragon, "Thermal and degradation behavior of fique fiber reinforced thermoplastic matrix composites," Journal of Thermal Analysis and Calorimetry, vol. 73, no. 3, pp. 783-795, 2003.

[29] D. Aht-Ong and K. Charoenkongthum, "Thermal properties and moisture absorption of LDPE/banana starch biocomposite films," Journal of Metals, Materials and Minerals, vol. 12, no. 1, pp. 1-10, 2002.

[30] A. Morales, D. Victoria, M. Ponce, and T. Lozano, "Materiales reforzados de poliolefinas recicladas y nanofibras de celulosa de henequén," Revista Iberoamericana de Polímeros, vol. 12, no. 5, pp. 255-267, 2011.

[31] A. Amash and P. Zugenmaier, "Morphology and properties of isotropic and oriented samples of cellulose fibre-polypropylene composites," Polymer, vol. 41, no. 4, pp. 1589-1596, 2000.

[32] T. N. Mtshali, I. Krupa, and A. S. Luyt, "The effect of crosslinking on the thermal properties of LDPE/wax blends," Thermochimica Acta, vol. 380, no. 1, pp. 47-54, 2001.

[33] Q. Fu, Y. Men, and G. Strobl, "Understanding of the tensile deformation in HDPE/LDPE blends based on their crystal structure and phase morphology," Polymer, vol. 44, no. 6, pp. 1927-1933, 2003. 

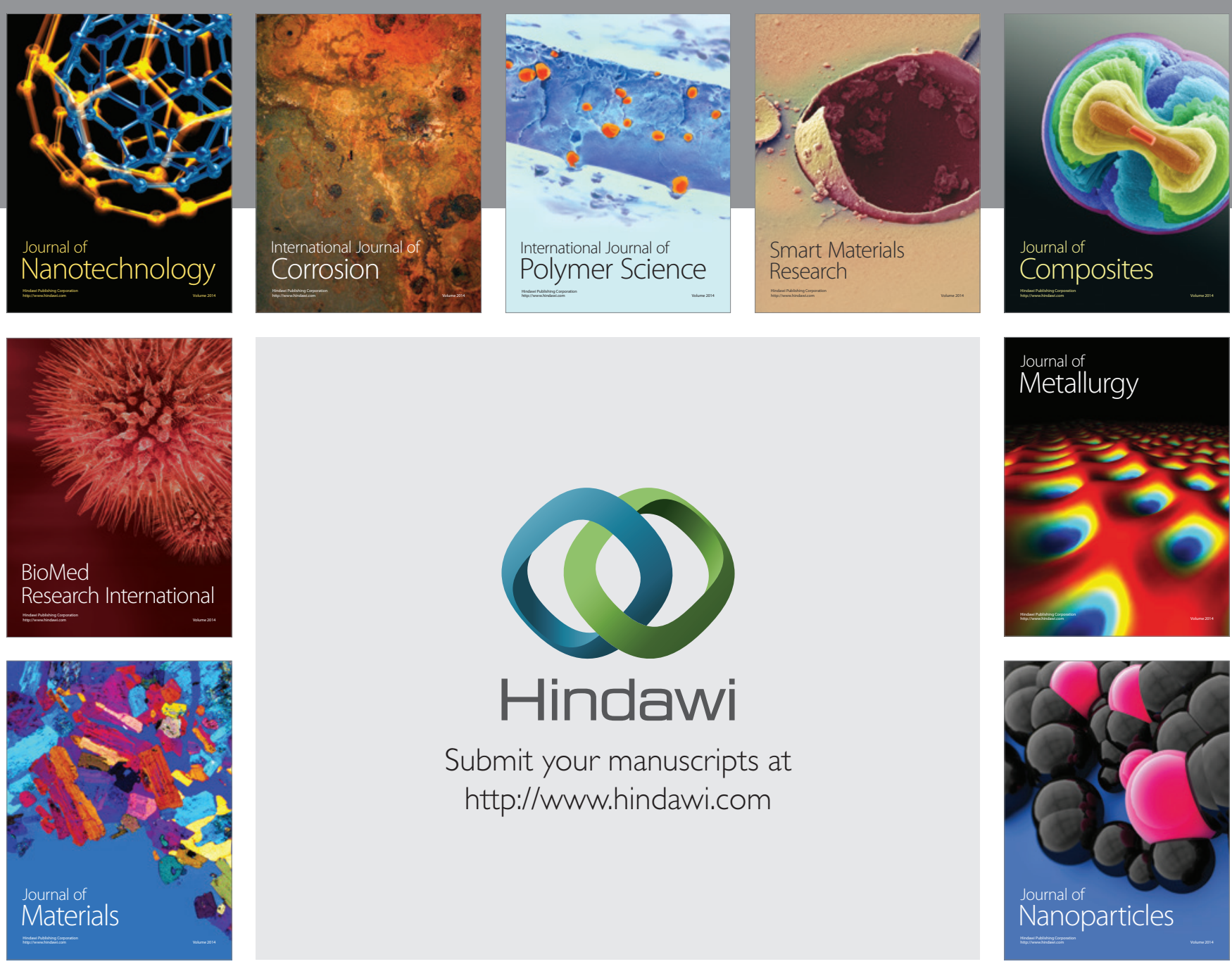

Submit your manuscripts at http://www.hindawi.com
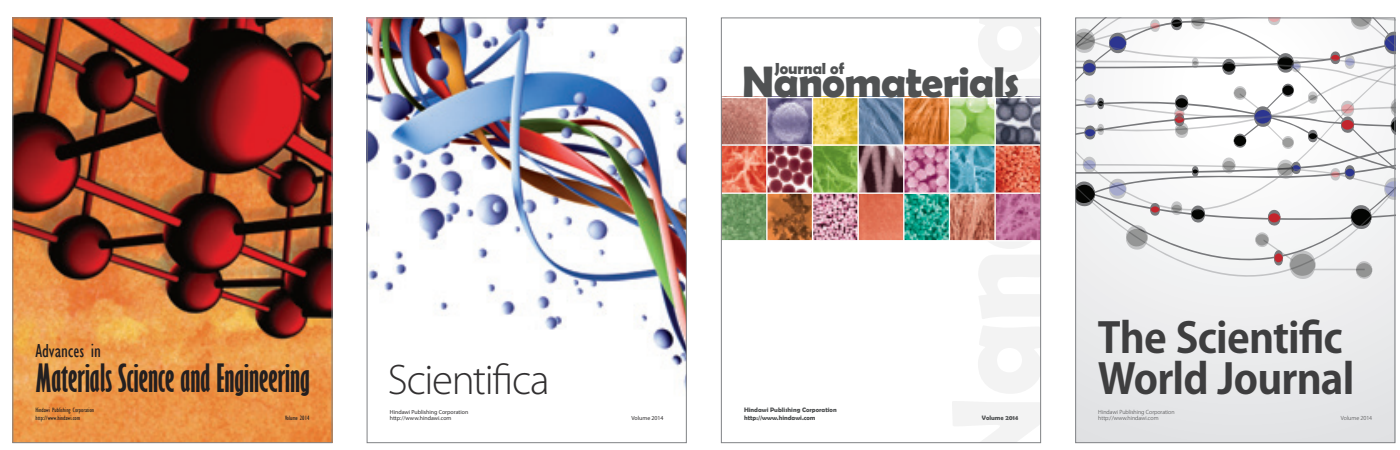

\section{The Scientific World Journal}
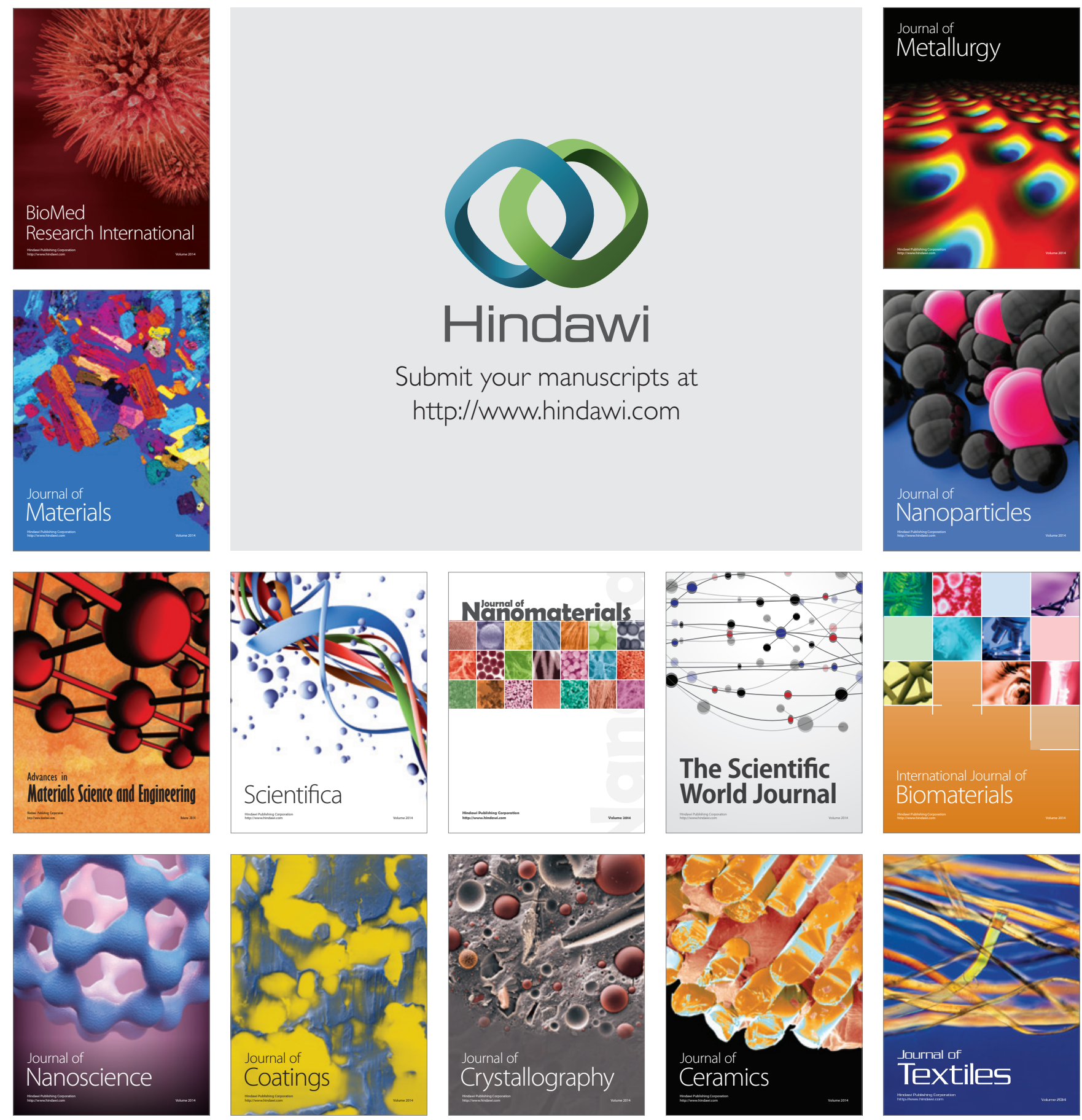